DOI: 10.14526/2070-4798-2019-14-3-73-76

\title{
Psychological support organization among young female volleyball players in the training process
}

\author{
Natalya N. Belyakova ${ }^{1}$, Natalya N. Romanova ${ }^{2 *}$, Yan V. Latyushin ${ }^{2}$, Dmitriy A. Dyatlov ${ }^{2}$ \\ ${ }^{1}$ Sports school of the Olympic reserve "Yunost-Metar" \\ Chelyabinsk, Russia \\ ORCID: 00oo-0002-7979-2607, romanova-natasha@mail.ru \\ ${ }^{2}$ Ural State University of Physical Culture \\ Chelyabinsk, Russia \\ ORCID: 00oo-0oo2-6373-6096, romanova-natasha@mail.ru* \\ ORCID: oooo-0oo3-1968-2315, valeas1@yandex.ru \\ ORCID: 00oo-0002-0962-4704,dokchel@mail.ru
}

\begin{abstract}
The article reveals the main characteristics of modern demands placed on young volley-ball players. The article substantiates the necessity to organize psychological support in a chosen kind of sport. The research methods and the results are presented, received during the mentioned methods use. We underline the role of a coach and sports psychologist during the process of young female volleyball players training. Mentioned urgent objective difficulties, which prevent effective psychological support realization, are enumerated. We showed the direction of sports psychologist's work in a team kind of sport. Research methods. Information sources analysis, survey, questionnaire survey, observation, conversation. Materials. During group and individual work we diagnosed the existing realized and unconscious difficulties, which inhibit the effectiveness of young female volleyball players during trainings. Research methods, used in the work, helped to gather, group, systematize and analyze the received information. The received information gives an opportunity to form more competent psychological team support. Results. During nonparticipant observation we revealed that it is difficult for young players to concentrate attention on the training process peculiarities, switch attention form life, everyday difficulties and the difficulties, which appear in educational process beyond sports school, to the situation at sports gym. In terms of agerelated and gender peculiarities it is difficult for young athletes to cope with the appearing emotional states. States influence psychic processes. The processes prevent potential realization. The absence of information, concerning psychology of sport, and lack of experience also have negative influence on the training process effectiveness. Conclusion. Psychological support organization among young female volleyball players is a difficult process, which demands attention from a coach and sports psychologist. This procedure demands maximum specialists' concentration on the details of the kind of sport, personal characteristics of each player in a team (including substitute players) and the objectives, set by a coach.
\end{abstract}

Keywords: psychological support, young female volleyball players, training process.

For citation: Natalya N. Belyakova, Natalya N. Romanova*, Yan V. Latyushin, Dmitriy A. Dyatlov. Psychological support organization among young female volleyball players in the training process. Russian Journal of Physical Education and Sport. 2019; 14(3): 73-76. DOI: 10.14526/2070-4798-2019-14-3-73-76

\section{INTRODUCTION}

Playing kinds of sport provide athletes' wide range of psychological characteristics. Necessary personal and professional traits would help players to cope with tight schedule of a regular Championship and also play-off games, stand the pressure of the teaching staff, the directors' of clubs and sports schools, panel of judges, opponent and fans, avoid extreme influence of negative emotions on own behavior, ecologically overcome failures, including a long-term period of not successful matches.

For volleyball it is typical to have small amount of players on the playing ground and it provides increased responsibility for each action, each made decision. Effective opponent's maneuvers change, attacking strikes blocking, deceitful actions concerning the choice of volleyball players and the place on the playing ground for the planned playing combinations realization increase pressing upon each player. If we take into account that in this case there is permanent deficiency of time for the set plans realization, it is not difficult to picture psychological state of any team player after the held match.

Nowadays the heads of sports schools and the training staff face the range of difficulties during 
the attempt to organize psychological support in teams and individual kinds of sport. Difficulties also include qualified staff hiring, who have sufficient experience, not only theoretical information, lack of financing, skeptical and sometimes negative attitude of athletes and their parents to the work of sports psychologist. Before starting the ideas realization, concerning training process quality improvement, it is necessary to overcome the range of direct and latent difficulties.

Sports psychologist also has a lot of difficulties, which he has to overcome in his professional activity. It is important to have contact with athletes, form necessary psychological distance, which will help to communicate and prove athletes the importance of sports psychology during training process organization. In terms of age related and gender peculiarities very often players try to show independence of own ideas, neglect the advantage of sports psychology in order to restrict access to personal information for the unknown person. Fear of being misunderstood, rejected or defeated also influences the athletes.

In our opinion, it is very important to organize psychological support of athletes. The urgency of the studied question is proved by several research works of different time range, connected with psychological training of sports reserve in different conditions, such as higher education $[5 ; 6 ; 7 ; 8 ; 9]$ and the stages of a long-term training in sport $[1 ; 2$; $3 ; 4 ; 10]$.

\section{MATERIALS AND METHODS}

During the experimental work we communicated with the players of Municipal budgetary establishment "Sports school of the Olympic reserve "Yunost-Metar"” in Chelyabinsk. The respondents were 33 female volleyball players at the age of 11-14.

During the research at the initial stage we used the following methods: scientific literature analysis, observation, survey, conversation, questionnaire survey.

Further we will present the results of the mentioned methods use.

Results and Discussion

Scientific literature analysis helped to prove the urgency of the studied process. We compared literature sources of different dates, as it was mentioned by us above, which are connected with different degree of athletes' readiness and different level of research works. These research works were devoted to sports schools, sport clubs, professional training of athletes-students in terms of higher physical culture and sports education.

Conversation as a method, which helps to get the information by means of continuous opinions sharing, gave us information concerning the attitude of female volleyball players to the work of sports psychologist, their expectations, notions of prospects for each athlete and the team in general. Athletes expressed their fears, shared the reasons for their fear. In particular, volleyball players doubted if it was possible to rely on unknown person and organize conversations, taking into account individuality of each player and the set relations in a team. Most of all young volleyball players worried about the trust.

Female athletes worried about the possibility of personal information distribution by the specialist in order to improve the results of teams-opponents in the future, or this material presentation to the coach, parents or the head of a sports school without their permission. The expresses doubts helped to set the contact between sports psychologist and the team, psychological distance decreased and necessary rules of dialogue and polylogue organization. When all interesting for female volleyball players questions were answered, all conflict situations were solved by constructive means. We set a positive contact with the team, positive attitude to the psychologist's activity, regardless of lack of information concerning all peculiarities of the future work.

Then during the method of conversation realization we received the information, concerning difficulties of psychological order, which appear among players during the training lessons and competitions. Young athletes came to the conclusion that it is difficult for them to concentrate their attention and hold considerable amount of objects within the field of vision. This situation becomes more complicated, as the difficulties, which appear in family and interteam relations, taking into account gender differences, and also educational establishments, present a distorting factor, which makes the situation on the playing ground worse. They mentioned positive attitude of a coach to each players, his desire to help when it was necessary. At the same time, most female athletes mentioned the problems in the existing eclectic data systematization, lack of knowledge concerning special psychological training for competitions.

By means of nonparticipant observation, which means that the scientist gets the information about the studied group, not being involved into the events and not becoming the member of the team, we received the verification of the expressed opinions of the athletes and also mentioned the range of objectives, which are connected with other features of attention. Apart from attention volume, concentration and distribution, the difficulties concerned the attention ability of switching and steadiness. It was also revealed that gender aspect influences greatly all indices of athletes' attention, influences their psychic and emotional state, decreases the effectiveness of the training process, decreases the level of positive in team in general.

Verbal-communicative method of survey, directed toward interaction realization between the 
scientist and the respondents by means of getting answers from the athletes, questionnaire survey, realized by means of indirect communication, helped us to prove the results, received during the conversation and observation. This prevented randomnicity of female athletes' answers, helped to be sure of the received information.

Psychological training we consider from the position of the following aspects:

- training for a continuous training process;

- psychic states correction at the final stage of training for competitions;

- general training for competitions;

- specialized training for competitions.

As the structure of psychological support organization among young female volleyball players in the training process we offer the following research methods and forms of psychological work use.

At the initial stage the methods of survey, questionnaire survey, observation and conversation are used.

Then, after qualitative information gathering, it is reasonable to organize the following:

- psychological diagnostics (standardized and projective testing, content-analysis);

- psychological consulting (on request of young athletes, as a result of psychological test, depending on psychic and emotional state in terms of the separate training day);

- psychological trainings (for group mastering of personal and professional difficulties, teambuilding, new ways of open emotions reaction searching, ecological models of behavior adoption);

- playing methods (business, organizationalactivity based, imitating games);

- debating methods (free and directed discussions).

This approach, in our opinion, will help to set psychological contact quickly, realize necessary information gathering loss-free, systematize the received results, cope with the appearing difficulties quickly, prevent conflicts, which can become longterm conflicts with personal complaints on the ground in terms of training and competitions.

\section{CONCLUSION}

Psychological support organization among young female volleyball players is the process, which demands great amount of energy, directed toward maximum result achievement concerning each player. The success of activity and stability of the received result depends on qualification of sports psychologist, the level of awareness among sports school administration and the training staff.

Sometimes it is difficult for young athletes to cope with psychological pressure, life and professional problems because of gender and age relate peculiarities. They lack experience in difficult problems solution of constructive relations formation even in situation of views clash, all features of attention focusing in order to achieve set by a coach aims and objectives and in order to realize personal professional ideas.

Thus, competently organized psychological support of the training process among 11-14 yearold female volleyball players will help to reveal the potential of each athlete, organize the training process effectively, to cope with conflicts without time loss and negative emotions.

\section{REFERENCES}

1. Ilin E.P. Psihologiya sporta [Psychology of sport]. Saint-Petersburg: Piter. 2008: 352.

2. Ilin E.P. Psihologiya fizicheskogo vospitaniya [Psychology of physical upbringing]. Mos-cow: Prosveshchenie. 1987: 287.

3. Nadrgulov A.R. Psychological aspects of 14-17-year-old hockey players training. Prob-lemy podgotovki nauchnyh I nauchno-pedagogicheskih kadrov: opyt I perspektivy; sbornik nauchnyh trudov molodyh uchenyh, posvyachennyj Dnyu rossijskoj nauki [Problems of training scientific and scientific-pedagogical staff: experience and prospects; collection of scientific works of young scien-tists, dedicated to Russian science Day]. 2018: 143-146.

4. Pavlyuchkov A.A. The peculiarities of divergent thinking formation among young foot-ball players. Problemy podgotovki nauchnyh I nauchnopedagogicheskih kadrov: opyt I perspektivy; sbornik nauchnyh trudov molodyh uchenyh, posvyachennyj Dnyu rossijskoj nauki [Problems of train-ing scientific and scientific-pedagogical staff: experience and prospects; collection of scientific works of young scientists, dedicated to Russian science Day]. 2019: 180-182.

5. Rendikova A.V. Possibilities of students psychological support optimization at UralSUPC. Optimizaciya uchebno-vospitatel'nogo processa $\mathrm{v}$ obrazovatel'nyh organizaciyah fizi-cheskoj kul'tury: materialy XXIX regional'noj nauchnometodicheskoj konferencii [Educational-upbringing process optimization in physical culture educational establishments: materials of the XXIX regional scientific-methodical conference]. Chelyabinsk: UralSUPC. 2019: 185-187.

6. Rendikova A.V. Psychological maintenance of students from Ural State University of Physical Culture. Optimizaciya uchebno-vospitatel'nogo processa v obrazovatel'nyh organizaciyah fizicheskoj kul'tury: materialy XXVIII regional'noj nauchnoprakticheskoj konferencii [Educational-upbringing process optimization in physical culture educational establishments: materials of the XXVIII regional scientific-methodical conference]. Chelyabinsk: UralSUPC. 2018: 147-148.
7. Romanova N. 
emotional states reflection development among the fu-ture physical culture teachers. Pedagogikopsihologicheskie I medico-biologicheskie problem fizi-cheskoj kul'tury I sporta = Pedagogicopsychological and medico-biological problems of physical culture and sport. 2014; 4(29): 155-160.

8. Romanova N.N. Celostnyj podhod v professional'noj podgotovke studentov vuza fizicheskoj kul'tury I sporta: monografiya [Integral approach in professional training students of physi-cal culture higher educational establishment: monograph]. Chelyabinsk: UralSUPC. 2019: 138167.

9. Romanova N. N. Experimental substantiation of the effectiveness of emotional states re-flection development methodology among the future physical culture specialists. Teoriya I praktika fizicheskoj kul'tury $=$ Theory and practice of physical culture. 2010; 1: 13-15.

10. Khrisanfova N.V., Latyushin Ya.V. Nervous system characteristics study of athletes, who specialize in average distance running. Problemy sovremennogo pedagogicheskogo obrazovani-ya. 2017; 57-7: 299-305.

11. Hughes G., Watkins J., Owen N. Gender differences in knee kinematics during land-ing from volleyball block jumps. Human Movement Studies. 2007; 53: 1-20.

12. Pisot R., Valencic V., Simunic B., Praprontnik U. Influence of biomechanical properties of particular skeletal muscles on child motor development. In Proceedings of the International Sport Medicine Conference. 26-29 September 2001. 2001: 176-177.

13. Salci Y., Kentel B.B., Heycan C., Akin S., Korkusuz F. Comparison of landing ma-neuvers between male and female college volleyball players. Clinical Biomechanics. 2004; 19: 622-628.

\section{Submitted: 07.08.2019}

Author's information:

Natalya N. Belyakova - Coach, Sports school of the Olympic reserve "Yunost-Metar", 454031, Russia, Chelyabinsk, Cherkasskaya str., House 1, e-mail: romanova-natasha@mail.ru

Natalya N. Romanova - Candidate of Pedagogics, Ural State University of Physical Culture, 454091, Russia, Chelyabinsk, Ordzhonikidze str., House 1, e-mail: romanova-natasha@mail.ru

Yan V. Latyushin - Doctor of Biological Sciences, Ural State University of Physical Culture, 454091, Russia, Chelyabinsk, Ordzhonikidze str., House 1, email: valeas1@yandex.ru

Dmitriy A. Dyatlov - Doctor of Biological Sciences, Ural State University of Physical Culture, 454091, Russia, Chelyabinsk, Ordzhonikidze str., House 1, email: dokchel@mail.ru 